\title{
Re-evaluation of the activity of the Thoen Fault in the Lampang Basin, northern Thailand, based on geomorphology and geochronology
}

\author{
Weerachat Wiwegwin ${ }^{1}$, Yuichi Sugiyama ${ }^{2}$, Ken-ichiro Hisada ${ }^{1}$, and Punya Charusiri ${ }^{3}$ \\ ${ }^{1}$ Graduate School of Life and Environmental Sciences, University of Tsukuba, Ibaraki 305-8572, Japan \\ ${ }^{2}$ Active Fault and Earthquake Research Center, National Institute of Advanced Industrial Science and Technology (AIST) 7. \\ 1-1-1 Higashi, Tsukuba, Ibaraki 305-8567, Japan \\ ${ }^{3}$ Earthquake and Tectonic Geology Research Unit (EATGRU), clo Department of Geology, \\ Faculty of Science, Chulalongkorn University, Bangkok 10330, Thailand
}

(Received September 7, 2010; Revised February 21, 2011; Accepted June 1, 2011; Online published January 26, 2012)

\begin{abstract}
We applied remote sensing techniques and geomorphic index analysis to a study of the NE-SW-striking Thoen Fault, Lampang Basin, northern Thailand. Morphotectonic landforms, formed by normal faulting in the basin, include fault scarps, triangular facets, wine-glass canyons, and a linear mountain front. Along the Thoen Fault, the stream length gradient index records steeper slopes near the mountain front; the index values are possibly related to a normal fault system. Moreover, we obtained low values of the ratio of the valley floor width to valley height (0.44-2.75), and of mountain-front sinuosity (1.11-1.82) along various segments of the fault. These geomorphic indices suggest tectonic activity involving dip-slip displacement on faults. Although the geomorphology and geomorphic indices in the study area indicate active normal faulting, sedimentary units exposed in a trench at Ban Don Fai show no evidence of recent fault movement. In Ban Don Fai trench No. 2, accelerator mass spectrometry radiocarbon (AMS) ages and optically stimulated luminescence (OSL) ages indicate that deposition of the lowest exposed sedimentary unit occurred between 960 and 910 years ago. Therefore, the most recent movement upon the Ban Don Fai segment of the Thoen Fault occurred more than 960 years ago.

Key words: Thoen Fault, normal faulting, morphotectonic landforms, geomorphic index analysis, OSL dating, AMS radiocarbon dating, Lampang Basin, Northern Thailand.
\end{abstract}

\section{Introduction}

Thailand is located to the east of the Andaman-Sumatra earthquake belt, and no large earthquake (i.e., magnitude $\geq 6$ on the Richter scale) has recently occurred in this region. Thus, Thailand has not been considered a seismically active country. However, historical earthquakes in Thailand have been reported by Nutalaya et al. (1985), based on historical texts, annals, stone inscriptions, and astrological documents in the Thai language. These earthquakes are likely to have originated on the active faults of Myanmar and southern China (Fenton et al., 2003). Although a few moderate earthquakes (i.e., magnitude 3-6 on the Richter scale) have recently been recorded in Thailand, seismicity in Thailand is generally considered to be low, and there is no clear association of seismicity with mapped faults (Bott et al., 1997; Fenton et al., 2003). In addition, geological and geomorphological investigations reveal that Quaternary faults in northern Thailand are characterized by long recurrence intervals of thousands to tens of thousands of years (Bott et al., 1997; Kosuwan et al., 1999; Fenton et al., 2003).

Northern Thailand is located in an active tectonic zone (Nutalaya et al., 1985). The Cenozoic Lampang Basin is

Copyright (C) The Society of Geomagnetism and Earth, Planetary and Space Sciences (SGEPSS); The Seismological Society of Japan; The Volcanological Society of Japan; The Geodetic Society of Japan; The Japanese Society for Planetary Sciences; TERRAPUB.

doi:10.5047/eps.2011.06.018 bordered on its southeastern side by the Thoen Fault. Based on observations of lineaments using remote sensing, morphotectonic landforms, and micro-earthquakes (i.e., magnitude $\leq 3$ on the Richter scale), the Thoen Fault can be classified as active (Hinthong, 1995; DMR, 2006) (Fig. 1). Although no large earthquake has occurred within the Lampang Basin, micro-earthquakes are recorded by seismographs of the Thai Meteorological Department and the Royal Thai Navy Seismic Research Station. Seismogenic faults in this area have not been identified, and it is not certain whether micro-earthquakes in the Lampang Basin are caused by basement tectonics or active faulting. Therefore, to clarify the nature of this seismicity, we examined the paleoseismicity of faults along the border of the Lampang Basin.

In this paper, we document movements along the Thoen Fault (Fig. 1(B)). We used remote sensing techniques and aerial photographs to identify and analyze the characteristic morphotectonic landforms that result from fault movements along the southeastern margin of the Lampang Basin. Based on this analysis, we identified a suitable site for trenching, and compiled the trench-log stratigraphy at this site. Quaternary dating methods, including optically stimulated luminescence (OSL) and accelerator mass spectrometry (AMS) radiocarbon dating, were used to determine the ages of sedimentary layers in the trench. The Thoen Fault can be divided into six segments based on fault geometry: the Ban Don Fai, Ban Mai, Ban Mae Ip, Mae Than, Sop 


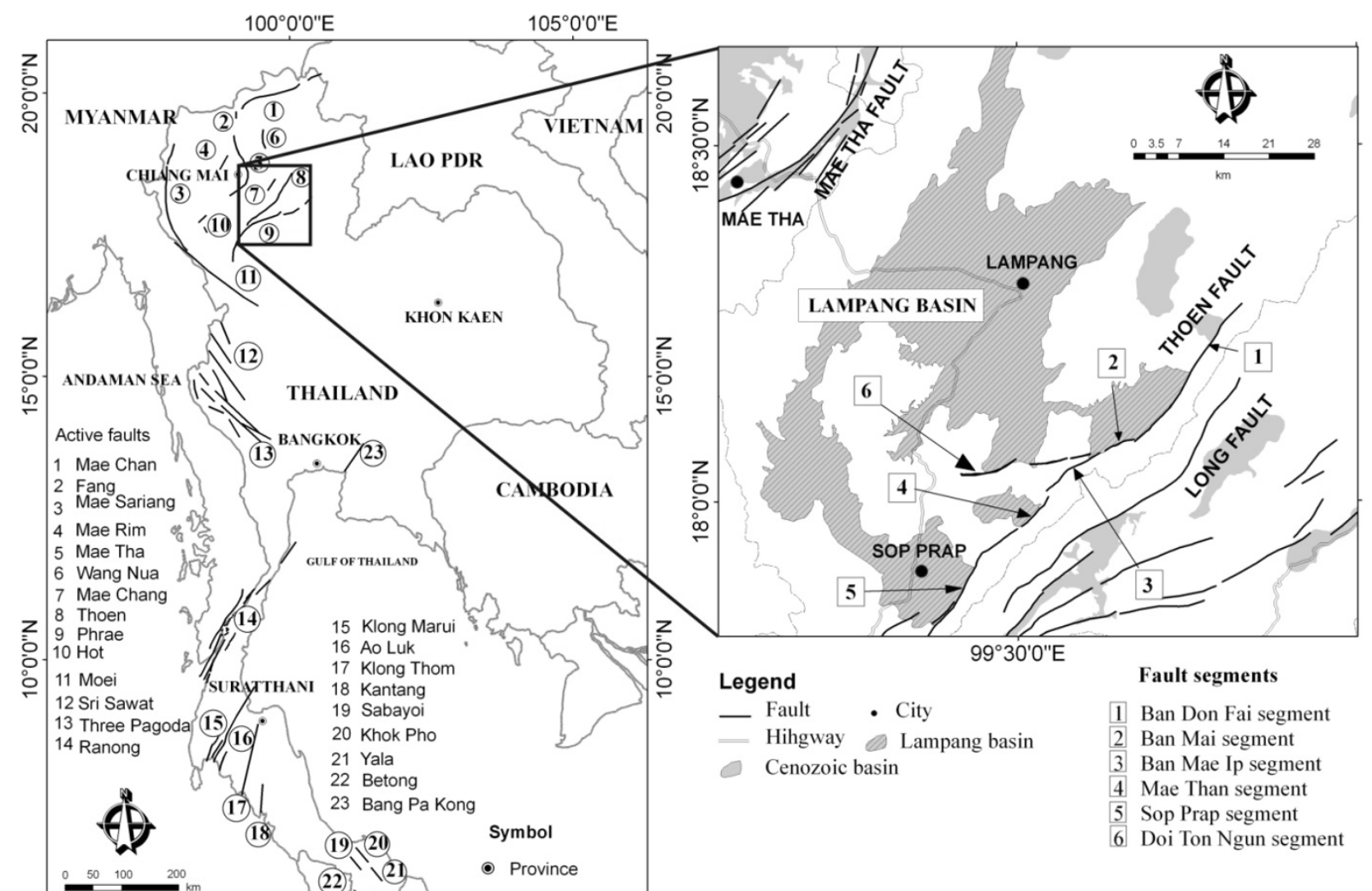

(B)

Fig. 1. Map of Thailand showing active faults (Hinthong, 1995) (A), and location of the Thoen Fault in the Lampang Basin (B).

Prap, and Doi Ton Ngun segments (Fig. 1(B)). Some of these segments were examined as part of a paleoearthquake study; however, paleoearthquake data are insufficient in terms of determining the timing of the most recent event. Trenching studies across the fault segments are necessary to reconstruct the history of displacement. Normal faulting along the Ban Don Fai segment has produced distinct morphotectonic landforms that represent the most important data in terms of site selection for a paleoearthquake study. Thus, our study focuses on the Ban Don Fai segment (segment 1 in Fig. 1(B)).

\section{Tectonic Setting}

The tectonic framework of SE Asia is dominated by the interaction of three major adjoining lithospheric plates: the continental-oceanic Indian Plate to the west and south, the continental Eurasian Plate in a central location, and the oceanic Philippine Plate to the east (Fenton et al., 2003). Thailand is part of the Eurasian Plate and lies to the east of an active east-dipping subduction zone that extends from north India (Himalaya Frontal Thrust), passes through west Myanmar and west of the Andaman and Nicobar Islands, and then swings eastwards along the Sumatra-Java trench (Reading, 1980) (Fig. 2). Major tectonic events may have occurred in the Indochina region during the late Paleogene (Peltzer and Tapponnier, 1988; Polachan et al., 1991; Charusiri et al., 2002, 2007) and are likely to have been related to the northwards and northeastwards progressive collision of the Indian and Eurasian plates (Peltzer and
Tapponnier, 1988; Charusiri et al., 2007).

In the Indochina region, since the late Paleogene, the collision of the Indian and Eurasian plates has resulted in predominantly strike-slip faults that strike NW-SE and NESW, and dip-slip faults that strike N-S (Tapponnier et al., 1986; Peltzer and Tapponnier, 1988). Important and wellknown fault zones in this region include the Red River Fault Zone in Vietnam (Tapponnier et al., 1986; Morley, 2007), the Sagaing Fault Zone in Myanmar (Tapponnier et al., 1986; Morley, 2007), and the Mae Ping and Three Pagoda fault zones in western Thailand (Morley, 2002; Fenton et al., 2003). During the late Eocene, collision of the Indian and Eurasian plates resulted in left-lateral displacements along the NW-SE striking Red River, Mae Ping, and Three Pagoda faults (Lacassin et al., 1997), but most recently these faults have been characterized by right-lateral displacements (Lacassin et al., 1997; Morley, 2002; Fenton et al., 2003). The left-lateral displacement along the Red River Fault amounted to hundreds of kilometers in the Eocene-Oligocene, related to extension within the South China Sea (Morley, 2002). The clockwise rotation of SE Asia coincided with a reversal in the sense of fault movement along the Mae Ping and Three Pagoda faults in the early Miocene, when these faults changed from left-lateral to right-lateral NW-SE-striking faults. At the same time, the Red River Fault continued as a left-lateral strike-slip fault (Huchon et al., 1994; Lacassin et al., 1997). By the middle Miocene, all of the NW-SE-striking strike-slip faults in the Indochina region (Red River, Mae Ping, and Three Pagoda 


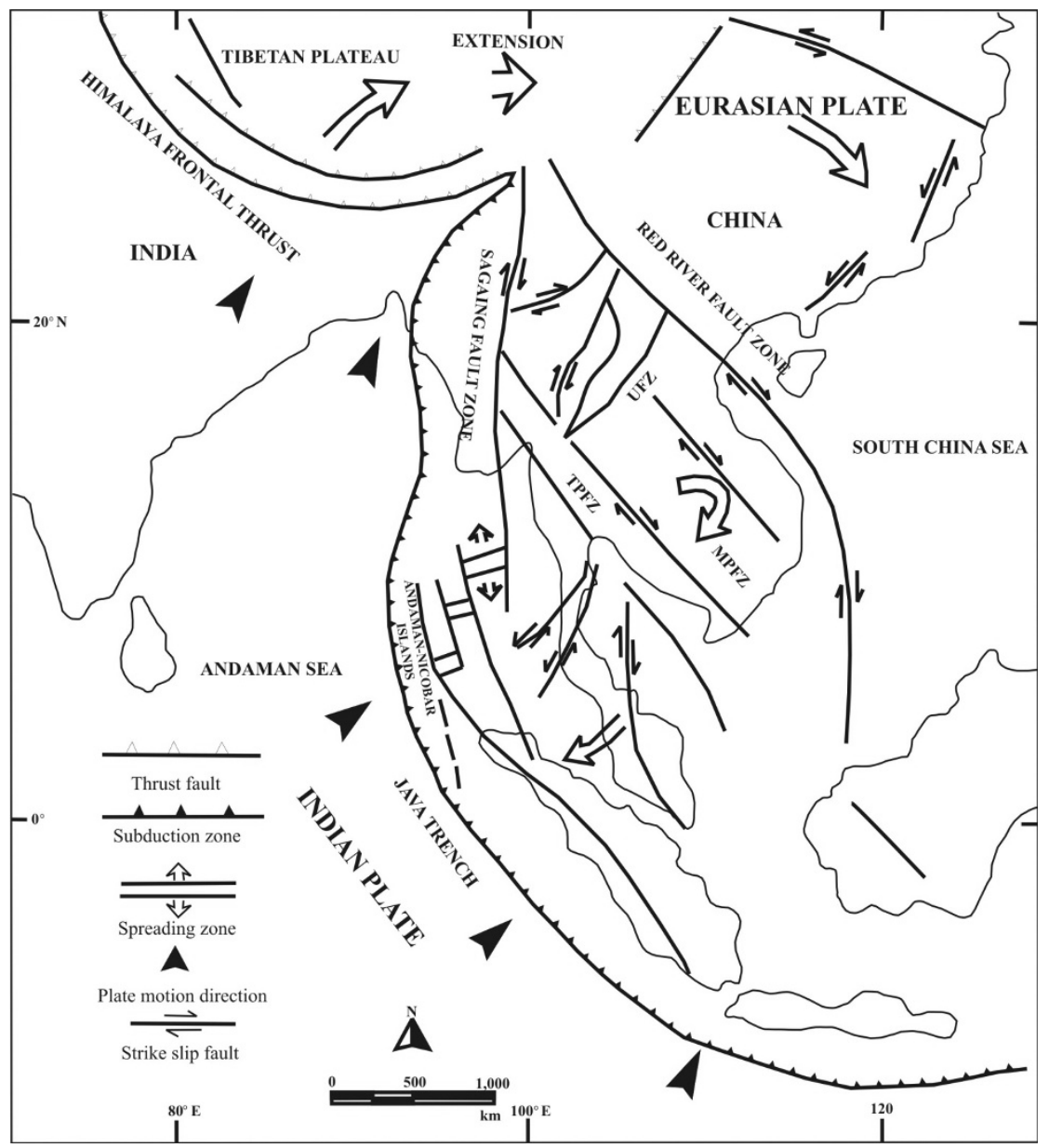

Fig. 2. Major tectonic elements in SE Asia and adjacent areas. Arrows show relative directions of plate movement during the late Cenozoic. TPFZ_-Three Pagodas Fault Zone; MPFZ_Mae Ping Fault Zone; UFZ—Uttaradit Fault Zone. (Modified from Polachan et al., 1991).

faults) had become right-lateral strike-slip faults (Longley, 1997). The main strike-slip faults (Red River, Mae Ping, and Three Pagoda faults) together form a transtensional regime that is related to the opening of Cenozoic basins in SE Asia (Ducrocq et al., 1992).

Thailand lies mainly in a zone of strike-slip deformation, between the Red River Fault Zone to the east and the compressive Sagaing Fault Zone to the west (Morley, 2007). Cenozoic basins in northern Thailand are mainly NS-trending graben and half-graben with sediments ranging in thickness from 1,000 to 3,000 m (Polachan et al., 1991). These Cenozoic basins are governed by N-S extensional faults which are inferred to be causally related to rightlateral slip movements on the NW-SE-striking faults, and left-lateral slip on the NE-SW-striking faults (Polachan et al., 1991; Packham, 1993). The geometries of the Cenozoic basins and the locations of faults may possibly be controlled by pre-existing fabrics in the basement rocks (O'Leary and Hill, 1989; Morley, 2007). A combination of both dip-slip and left-lateral strike-slip movement (i.e., oblique sinistral extension) is recognized as being required to explain the evolution of these basins (Morley et al., 2001, 2004, 2007; Morley, 2002, 2007).

\section{Active Faults in Thailand}

Paleoearthquake studies aim to determine the occurrence of past earthquakes on active faults. An active fault can be defined as one that has moved at least once during the period that includes the late Pleistocene and extends through to the present day (Geological Survey of Japan, 1983). Moreover, an active fault may generate another earthquake in the near future.

Based on seismological and geological evidence, Nutalaya et al. (1985) were the first to introduce the concept of seismic source zones in Thailand and neighboring countries. Hinthong $(1995,1997)$ conducted a project titled "Study of Active Faults in Thailand", and used geological, historical, and seismological data to identify 23 active or suspected active faults in Thailand (Fig. 1(A)). Siribhakdi (1986) studied seismogenic regimes in Thailand, and reported on the earthquakes that had occurred in Thailand throughout the past 1,500 years. Many of these earthquakes were closely related to the Three Pagoda Fault (number 13 in Fig. 1(A)), the Si Sawat Fault (12 in Fig. 1(A)), the Mae Ping Fault (Moei Fault of Hinthong (1995); 11 in Fig. 1(A)), and the Mae Hong Son Fault (Mae Sariang Fault of Hinthong (1995); 3 in Fig. 1(A)). Thiramongkol (1986) provided evidence of Holocene movement on the Bang $\mathrm{Pa}$ Kong Fault along the eastern margin of the lower central plain of Thailand (number 23 in Fig. 1(A)). Charusiri et al. 
(1996) applied several remote sensing techniques to a study of earthquakes in Thailand and neighboring countries. A seismotectonic (or seismic source) map was compiled by Charusiri et al. (1996). Rhodes et al. (2004) studied the kinematics of the Mae Kuang Fault in northeastern Chiang Mai, northern Thailand, and identified offset contacts and slickenlines on the surface of the fault, indicating a leftlateral slip of $3.5 \mathrm{~km}$ and a dip-slip of $600 \mathrm{~m}$. The authors suggested that the fault was initiated between 20 and $5 \mathrm{Ma}$, simultaneous with a reversal in the movement direction on the Mae Ping and Red River faults, and that it terminates at the northeastern margin of the Chiang Mai Basin. The Mae Kuang Fault does not extend to the western side of the Chiang Mai Basin because it is truncated by the right-lateral Mae Tha Fault.

The Thoen Fault in the Cenozoic Lampang Basin strikes NE-SW, and has been regarded as an active fault (Hinthong, 1995, 1997; Fenton et al., 1997, 2003). Based on morphotectonic landforms and geochronological data, the Department of Mineral Resources in Thailand (DMR, 2006) also classified the Thoen Fault as active. Quartz-rich samples from fault-related colluviums, and charcoal samples, provide displacement ages of 4,000, 3,000, and 2,000 years BP using thermoluminescence (TL) dating and the ${ }^{14} \mathrm{C}$ method, respectively (DMR, 2006). Moreover, from 1990 to the present day, more than two dozen earthquakes with magnitudes of $M_{\mathrm{b}}$ 3.0-5.0 have been detected near this fault. Danphaiboonphon (2005) studied the characteristics of the Thoen Fault, using remote sensing, petrographic analysis, and geophysical investigation, and suggested that it is an oblique strike-slip fault. Several lines of evidence, using geomorphology and stratigraphy, indicate that the Thoen Fault was an extensional structure during the Holocene (Fenton et $a l ., 1997,2003$ ), and that the displacements are mainly normal dip-slip and subordinate left-lateral slip. The slip rate of the fault is about $0.6 \mathrm{~mm} / \mathrm{yr}$ (Fenton et al., 2003). Pailoplee et al. (2009) excavated two trenches on the Ban Mai (number 2 in Fig. 1(B)) and Doi Ton Ngun (6 in Fig. 1(B)) segments of the Thoen Fault in the Lampang Basin. Based on trench-log interpretations, the Ban Mai segment records a single main paleoearthquake, at 3,800 years ago; the slip rate is approximately $0.06 \mathrm{~mm} / \mathrm{yr}$. The Doi Ton Ngun segment records evidence for two paleoearthquake events at 3,500 and 1,800 years ago; the average slip rate since the last fault movement is $0.18 \mathrm{~mm} / \mathrm{yr}$, and the recurrence interval for earthquakes is 1,700 years. Based on the current study of seismicity (i.e., the $b$ value of the GutenbergRichter (G-R) relationship, where a low value indicates high earthquake activity) upon the Thoen Fault (Lampang Basin) and upon the Phrae Fault (Phrae Basin), the $b$ value for the Thoen Fault is lower than that for the Phrae Fault (Pailoplee et al., 2009). Pailoplee et al. (2009) also suggested that the Thoen Fault in the Lampang Basin is capable of generating more earthquake activity than the Phrae Fault.

\section{Interpretation of Remote Sensing Data}

Lineaments and faults in the Lampang Basin and adjacent areas are visible on enhanced Landsat 7 images, mainly oriented NE-SW, with conjugate structures oriented NW-SE, along with some minor N-S structures (Fig. 3). The NE-
SW-striking fault that bounds the Lampang Basin is clearly visible along the southeastern side of the basin (Fig. 4). The total length of the Thoen Fault in the Lampang Basin is approximately $75 \mathrm{~km}$. The fault can be traced along the boundary between Triassic marine sandstone and unconsolidated Quaternary sediments that are mainly fluvial, colluvial, and alluvial deposits.

The Thoen Fault is well defined, visible as a sharp lineament on aerial photographs and satellite images (Fig. 4). Detailed interpretations of aerial photographs reveal fault scarps at Ban Mai, Ban Don Fai, and Ban Samai Nuea ((A) and (C) in Fig. 4), and reveal the following six geometrical fault segments along the southeastern margin of the Lampang Basin: Ban Don Fai, Ban Mai, Ban Mae Ip, Doi Ton Ngun, Mae Than, and Sop Prap (Fig. 1(B)).

The morphotectonic landforms observed in the Lampang Basin include fault scarps, triangular facets, wineglass canyons, and linear mountain fronts. A combination of vertical movement on range-bounding normal faults and stream incision in the valleys results in the formation of triangular facets. Triangular facets are roughly planar surfaces with broad bases and upwards-pointing apexes that occur between valleys (Keller and Pinter, 1996) (Fig. 5(B)). The occurrence of a sequence of displacements along a normal fault would produce a series of triangular facets (Hamblin, 1976; Fenton et al., 2003) (Fig. 5(D)). A series of triangular facets is found in the Lampang Basin along the NWfacing escarpment (Figs. 5(A) and 5(C)). Hamblin (1976) proposed that such features could result from episodic fault movement, and that the facets would form during fault movement while the benches form during the intervening periods of tectonic stability. According to this model, triangular facets first form by stream-cutting across the fault scarp (I-II in Fig. 6), producing a first set of triangular facets develop (II in Fig. 6). During a succeeding period of tectonic quiet, a narrow pediment develops (III in Fig. 6). Then, renewed displacement on the normal fault results in a new fault scarp (IV in Fig. 6), and streams develop on this new scarp. Thereafter, a second set of triangular facets develops ( $\mathrm{V}$ in Fig. 6). A succession of similar events would result in several sets of triangular facets (VI-VIII in Fig. 6). Based on this model, the triangular facets in the Lampang Basin might correspond to stage VIII. Triangular facets may be caused by lateral erosion or by differential erosion acting on a lithologic boundary between resistant and non-resistant rocks; however, several streams that cross the Ban Don Fai, Sop Prap, and Ban Mai segments pass through wine-glass canyons (Fig. 7) and V-shaped valleys. The presence of wine-glass canyons indicates steepening of the faceted spurs at the base of the escarpment, suggesting in turn that the Ban Don Fai and Ban Mai segments, and possibly other segments, are currently undergoing renewed or increasing vertical displacement. Rapid downcutting results in the formation of a narrow slot in a wineglass canyon. A line of small, triangular facets at the base of the range front coincides with the locations of a narrow slot in a wine-glass canyon, and with the surface trace of the Thoen Fault. A NW-facing escarpment of triangular facets is developed in Triassic marine sandstone, with slope angles $\left(50^{\circ}-60^{\circ}\right)$ steeper than the dip of bedding $\left(45^{\circ}-50^{\circ}\right)$. 


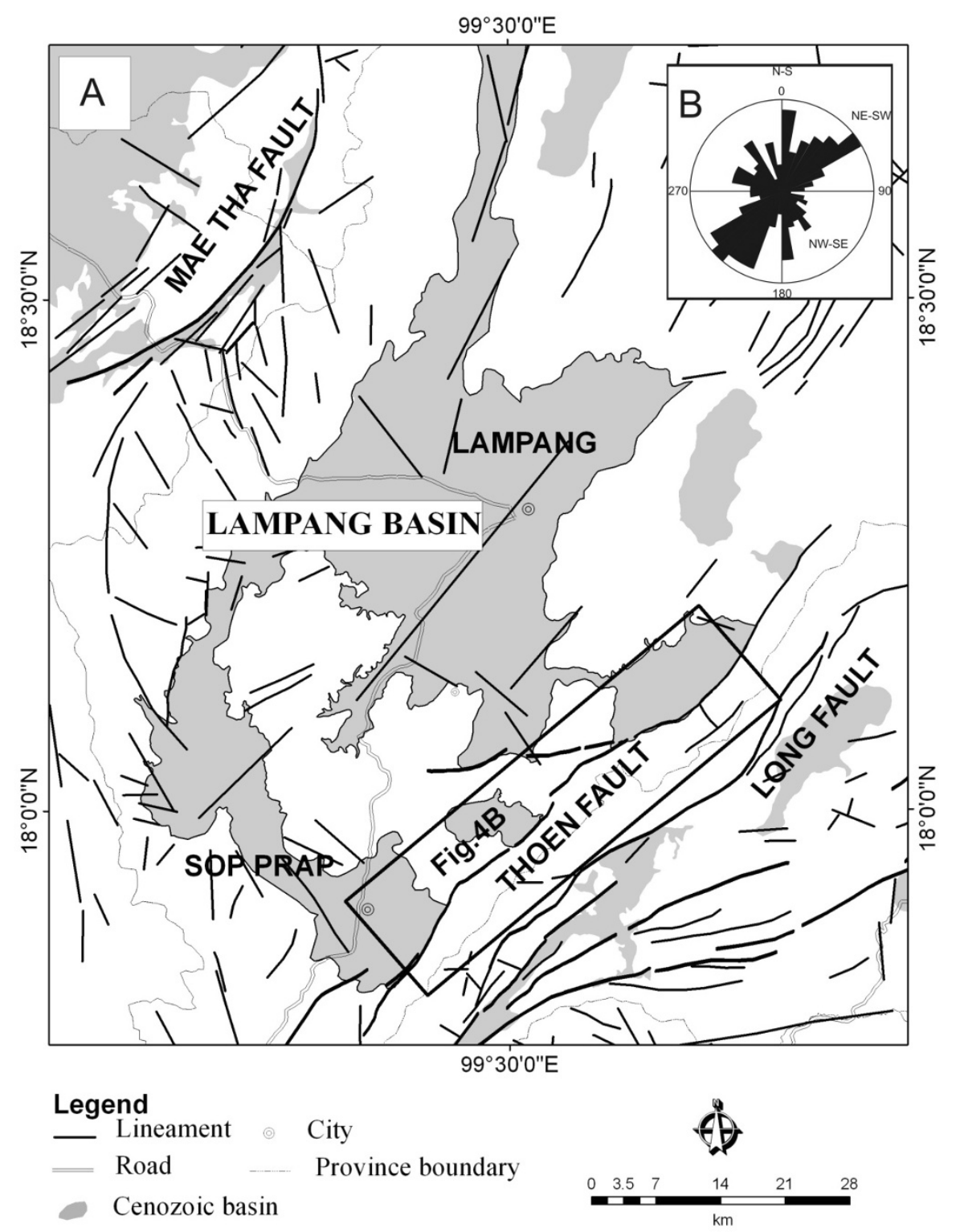

Fig. 3. Map showing lineaments in the Lampang Basin, northern Thailand (A), and a rose diagram of lineament orientations (B).

These morphotectonic landforms (i.e., triangular facets, Vshaped valleys, and wine-glass canyons) have been reported from other well-studied active fault zones and are considered to indicate mountain fronts bounded by active faults (e.g., Hamblin, 1976; Bull and McFadden, 1977; Wallace, 1978; Fenton et al., 2003; Ganas et al., 2005; Picotti et al., 2009). Our explanation of the origin of triangular facets is consistent with the findings of previous studies that linked facet formation to periods of active faulting.

\section{Analyses Based on Geomorphic Indices}

Geomorphic indices are useful for the level of tectonic activity, and zones of active tectonism (Keller and Pinter, 1996; Bull, 2008). Geomorphic indices represent preliminary tools for identifying areas that are experiencing rapid tectonic deformation (Keller and Pinter, 1996; Bull, 2008).
Geomorphic indices, including the stream length gradient index $(S L)$, the ratio of valley floor width to valley height $(V f)$, and mountain-front sinuosity $(\operatorname{Smf})$, were used in the present study to identify tectonic activity within the Lampang Basin. All the parameters for the geomorphic index analysis are taken from the Mae Tha (map sheet 4945 III) and Sop Prap (map sheet 4844 I) 1:50,000 topographic maps.

\subsection{Stream length gradient index $(S L)$}

The $S L$ index is correlated with stream power (Hack, 1973; Keller and Pinter, 1996). The total stream power available at any particular reach of a channel is an important hydrologic variable because it relates to the ability of a stream to transport sediments and erode its bed. The available stream power is proportional to the slope of the water surface and the discharge. The gradient of the water sur- 


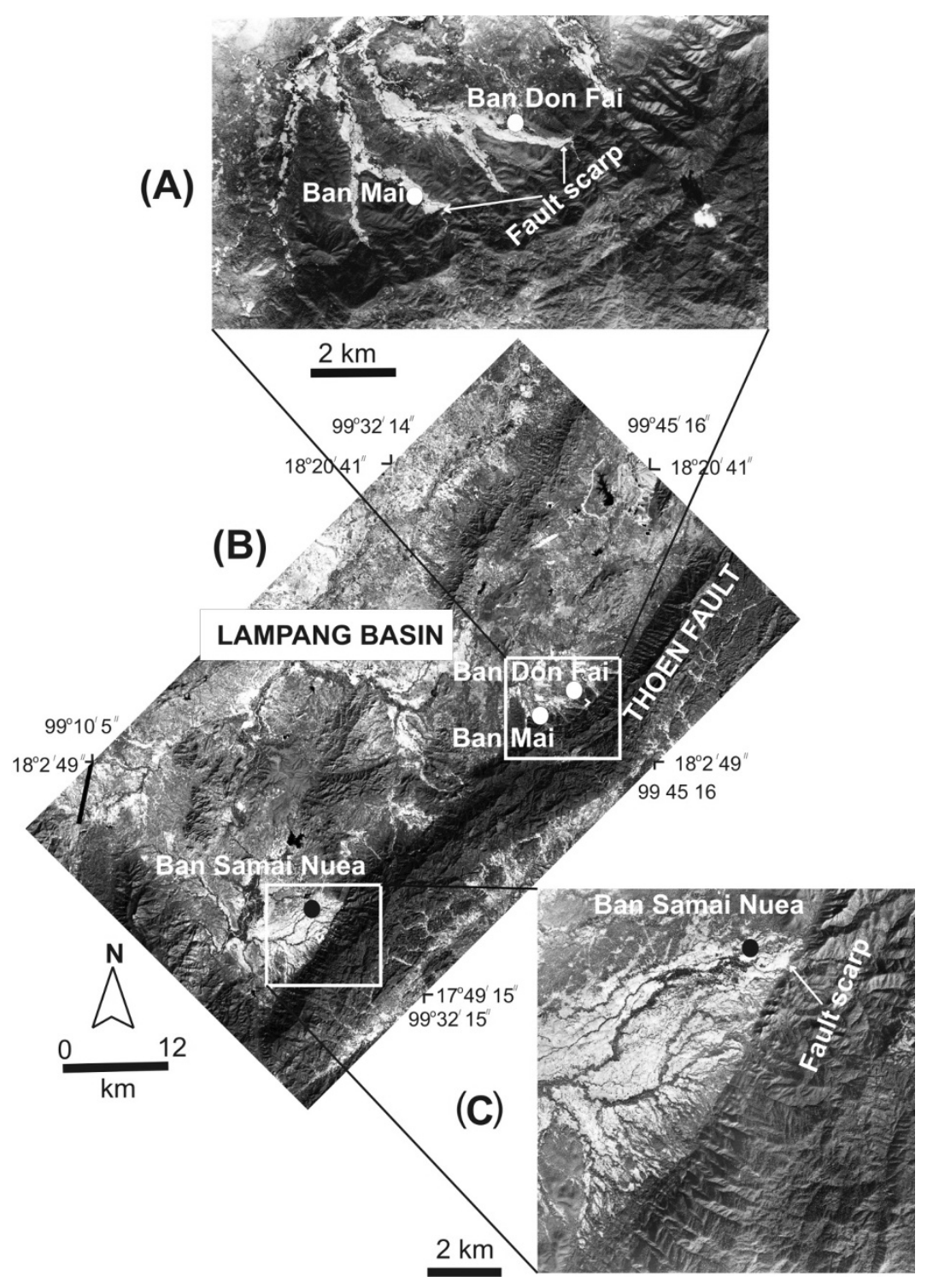

Fig. 4. Panchromatic Landsat image of the Thoen Fault in the Lampang Basin, showing a sharp lineament near Ban Mai, Ban Don Fai, and Ban Samai Nuea (B), and aerial photographs of the Thoen Fault showing the fault scarps at Ban Mai, Ban Don Fai, and Ban Samai Nuea ((A) and (C)). The location of this image is shown in Fig. 3.

face correlates with the channel slope (Keller and Pinter, 1996). The $S L$ index is a useful tool for evaluating changes in channel slope: high values are most simply related to resistant rock units, but they may also be related to the presence of an active tectonic zone (Keller and Pinter, 1996). The $S L$ index is calculated from the gradient of the reach and the total channel length, as follows:

$$
S L=(\Delta H / \Delta L) * L
$$

where $S L$ is the stream length gradient index, $\Delta H$ is the change in elevation of the reach, $\Delta L$ is the length of the reach, and $L$ is the total length of the channel from the point of interest to the highest point of the channel.

In the small river basins of an active tectonic area, the $S L$ index is a valid tool for detecting the incipient local processes of tectonic activity (Troiani and Della Seta, 2008). For our study, we measured the $S L$ index for streams around the southeastern margin of the Lampang Basin. $S L$ indices for the Ban Mai, Ban Don Fai, and Sop Prap segments ((A) and (B) in Fig. 8) indicate steeper slopes near the mountain front (360-400 $\mathrm{m}$ and $280-420 \mathrm{~m}$ in elevation) along the southeastern margin of the basin (Figs. 9 and 10). These steeper slopes may have developed from resistant bedrock located near the mountain front or as a consequence of active tectonics with a large component of vertical displacement. Based on a 1:250,000 geological map of the Mae Tha and Sop Prap areas, the Thoen Fault is located along the steeper slopes near the mountain front (DMR, 1994). Thus, these steeper slopes are possibly caused by normal dip-slip movement on the Thoen Fault.

\subsection{Ratio of valley floor width to valley height $(\mathrm{Vf})$}

The $V f$ index is the ratio between the width of the valley floor and the mean height of the valley. The index is sensitive to tectonic base-level falls, because a narrowing of a valley floor is caused by downcutting of the stream (Bull, 2008). High values of $V f$ are commonly associated with low uplift rates (where streams cut broad valley floors), whereas low values correspond to deep valleys 


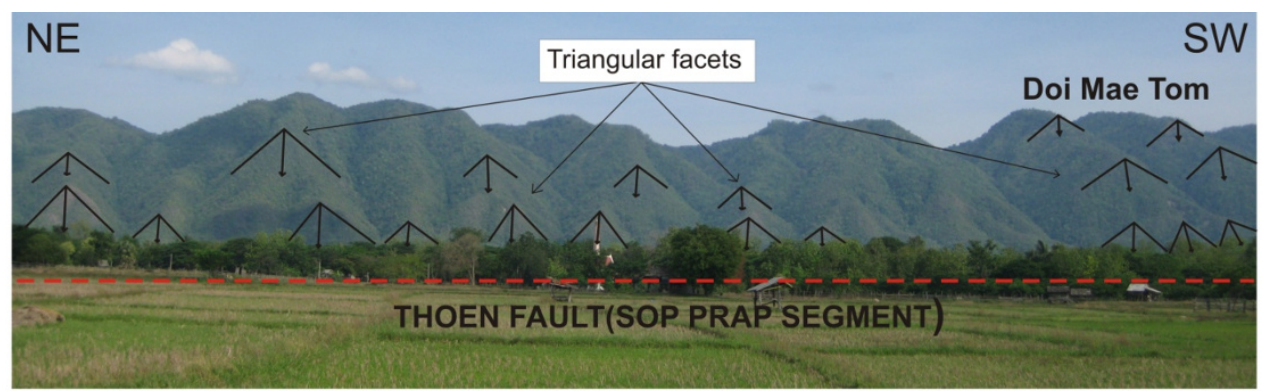

(A)
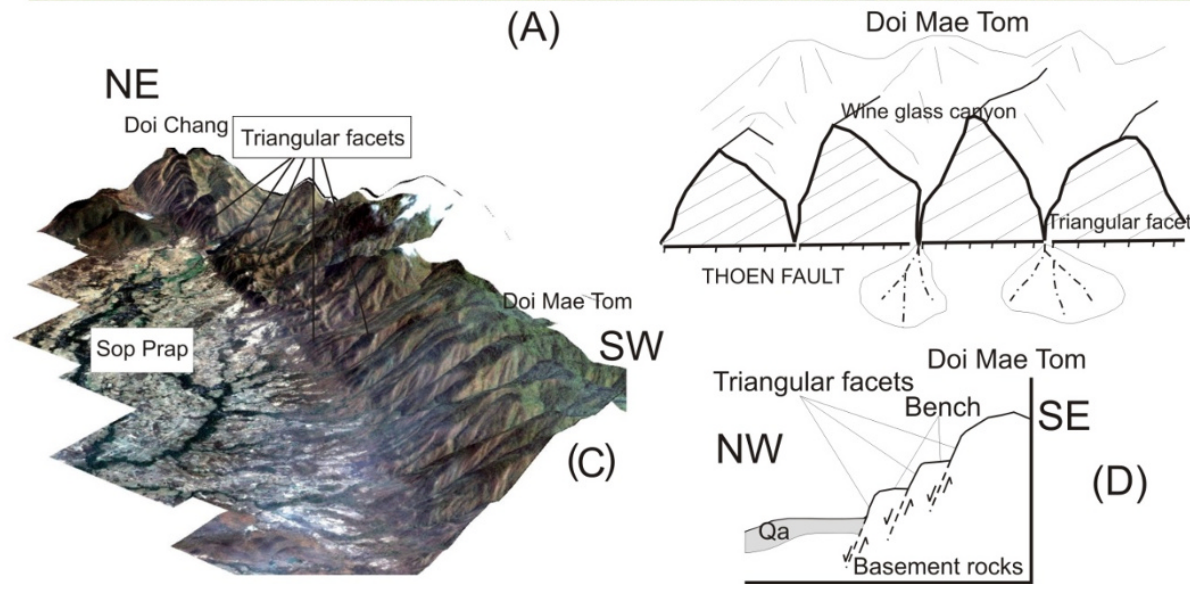

(B)

Fig. 5. Panoramic view of the NW-facing escarpment with three lateral series of triangular facets at Doi Mae Tom in the Sop Prap area (A); an idealized model showing triangular facets of the Lampang Basin (B); a three-dimensional model of the Ikonos image of the Sop Prap area, showing a series of triangular facets (C); and a NW-SE cross-section across Doi Mae Tom (D).
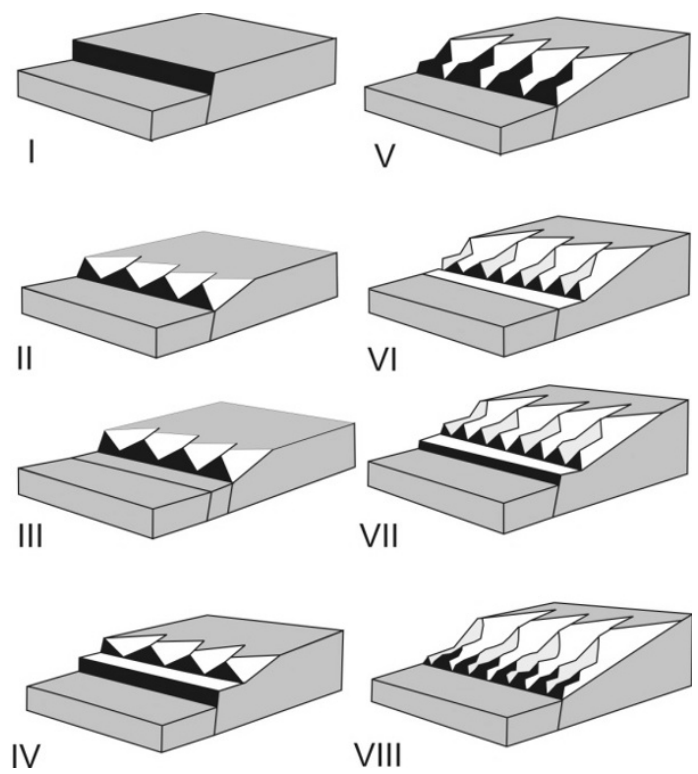

Fig. 6. Development of a series of triangular facets produced by vertical tectonic movement (modified from Hamblin, 1976).

(V-shaped valleys) that result from vertical incision of the stream (Keller and Pinter, 1996). The index is calculated as

$$
V f=2 V f w /((E l d-E s c)+(E r d-E s c))
$$

where $V f$ is the ratio of the valley floor width to valley height, $V f w$ is the width of the valley floor, and Eld and Erd are the elevations of the left and right valley divides, respectively. $E s c$ is the elevation of the valley floor.

Bull and McFadden (1977) showed that $V f$ values in the active tectonic zones of arid areas are characterized by $V f$ values from 0.05 to 0.9 , whereas $V f$ values in less active and inactive tectonic areas tend to fall in the ranges $0.5-$ 3.6 and 2-47, respectively. The $V f$ index has seldom been applied to active tectonic areas in the tropics. A $V f$ analysis along the Lo River Fault in northern Vietnam produced low values (0.06 to 0.61$)$, indicating recent uplift upon the fault (Cuong and Zuchiewicz, 2001).

In the present study, $V f$ values were determined for streams near the southeastern margin of the Lampang Basin. The values obtained for the Ban Mai, Ban Don Fai, 


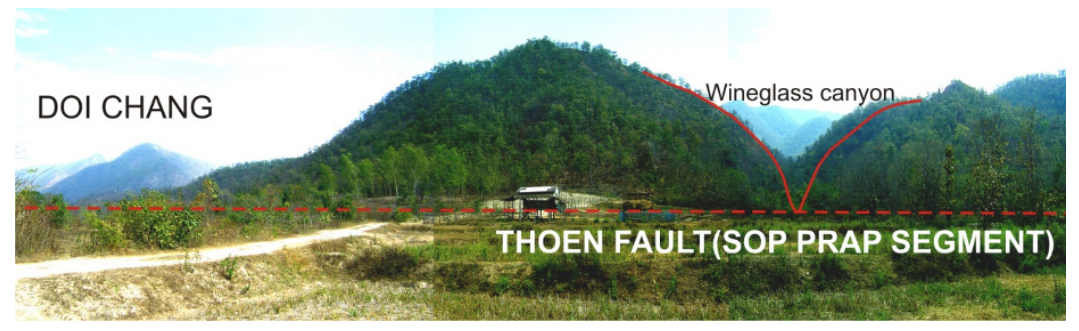

Fig. 7. Panoramic view of Doi Chang mountain, looking towards the SE, showing a wineglass canyon along the Sop Prap segment of the Thoen Fault.

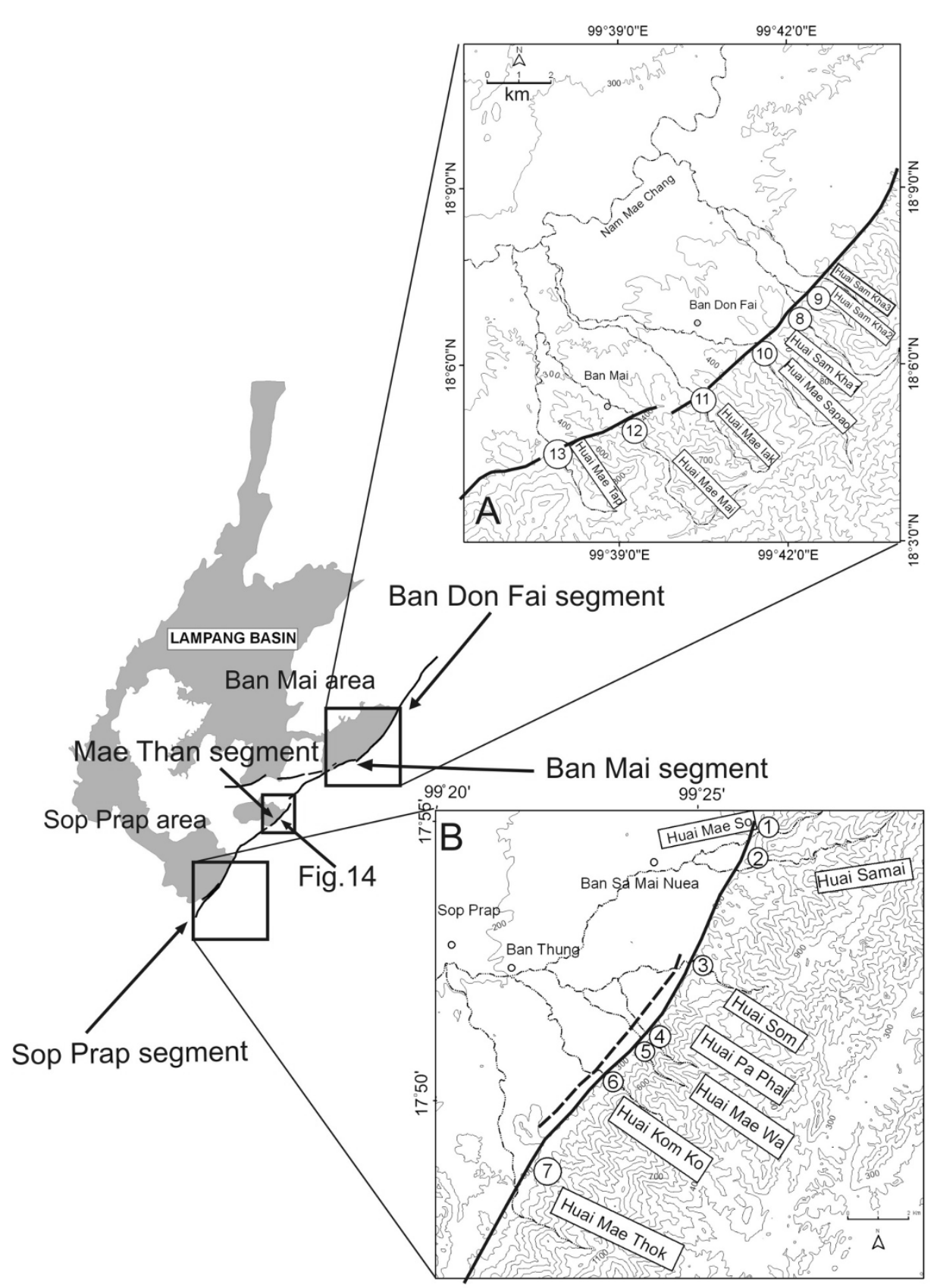

Fig. 8. Map showing the locations of streams used for calculating $S L$ and $V f$ indices, and trenching site. The numbers in circles indicate the locations of streams used for calculation of the $V f$ index. 


\section{Ban Mai and Ban Don Fai segments}

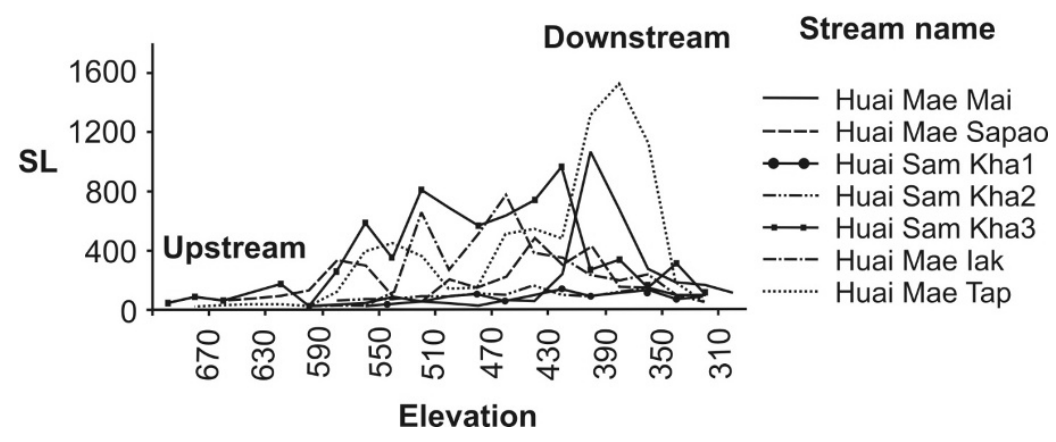

Fig. 9. Stream length-gradient index $(S L)$ analysis in the Ban Mai and Ban Don Fai segments. The figure shows steeper slopes near the mountain front, along the margin of the basin, at elevations of 360-400 $\mathrm{m}$ above m.s.l. Locations of streams are shown in Fig. 8 .

\section{Sop Prap segment}

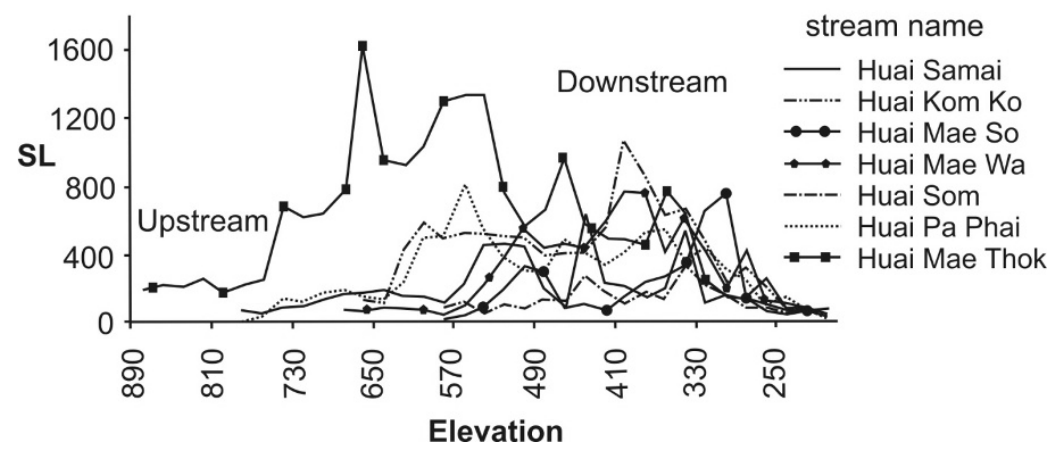

Fig. 10. Stream length-gradient index $(S L)$ analysis in the Sop Prap segment. The figure shows steeper slopes near the mountain front, along the margin of the basin, at elevations of 280-420 m above m.s.l. Locations of streams are shown in Fig. 8.

Table 1. Parameters for calculating the ratio of Valley floor width to Valley height $(V f)$ in the southeastern Lampang Basin.

\begin{tabular}{lccccc}
\hline $\begin{array}{l}\text { Sop prap area/Stream name } \\
\text { and location (No.) }\end{array}$ & $V f w(\mathrm{~m})$ & Eld $(\mathrm{m})$ & Erd $(\mathrm{m})$ & Esc $(\mathrm{m})$ & $V f$ \\
\hline Huai Mae So (1) & 104 & 480 & 460 & 360 & 0.95 \\
Huai Samai (2) & 100 & 380 & 360 & 300 & 1.40 \\
Huai Som (3) & 160 & 360 & 380 & 260 & 1.45 \\
Huai Pa Phai (4) & 76 & 340 & 360 & 300 & 1.52 \\
Huai Mae Wa (5) & 110 & 340 & 340 & 300 & 2.75 \\
Huai Kom Ko (6) & 81 & 360 & 380 & 300 & 1.16 \\
Huai Mae Thok Noi (7) & 76 & 380 & 360 & 300 & 1.09 \\
\hline Ban Mai Area/Stream name & & & & & \\
and location (No.) & $V f w(\mathrm{~m})$ & Eld (m) & Erd (m) & Esc (m) & $V f$ \\
\hline Huai Sam Kha1 (8) & 45 & 420 & 400 & 380 & 1.50 \\
Huai Sam Kha2 (9) & 87 & 560 & 600 & 380 & 0.44 \\
Huai Mae Sapao (10) & 119 & 580 & 560 & 380 & 0.63 \\
Huai Mae Iak (11) & 105 & 520 & 580 & 360 & 0.55 \\
Huai Mae Mai (12) & 67 & 350 & 460 & 340 & 1.03 \\
Huai Mae Tap (13) & 66 & 480 & 460 & 360 & 0.60 \\
\hline
\end{tabular}

Remarks

$V f w=$ Width of the valley floor $(\mathrm{m}) . E s c=$ Elevation of valley floor $(\mathrm{m}) . \quad$ Eld $=$ Elevation of left valley divide $(\mathrm{m}) . V f=$ Ratio of valley floor width to valley height. Erd $=$ Elevation of right valley divide $(\mathrm{m})$. $S m f=$ Mountain-front sinuosity. Locations of streams are shown in Fig. 8.

and Sop Prap segments vary from 0.44 to 2.75 (Table 1). Figure 8 shows the locations where $V f$ was determined. All of these sites are located within V-shaped valleys; however, smaller streams possess relatively little downcutting power. As a result, smaller streams tend to have lower $V f$ values than larger streams within the same tectonic regime (Wiltschko et al., 2010). Thus, the $V f$ values obtained in the present study are highly variable. 
Table 2. Parameters for calculating values of mountain-front sinuosity $(\mathrm{Smf})$ in the southeastern Lampang Basin.

\begin{tabular}{cccc}
\hline $\begin{array}{c}\text { Ban Mai } \\
\text { area/Location }\end{array}$ & Lmf $(\mathrm{m})$ & $\operatorname{Ls}(\mathrm{m})$ & $S m f$ \\
\hline 1 & 17525 & 14289 & 1.23 \\
2 & 1772 & 1154 & 1.54 \\
3 & 1325 & 1182 & 1.12 \\
4 & 1861 & 1678 & 1.11 \\
5 & 2040 & 1472 & 1.39 \\
6 & 1593 & 1040 & 1.53 \\
7 & 1764 & 1549 & 1.14 \\
8 & 2559 & 1874 & 1.37 \\
9 & 5842 & 4561 & 1.28 \\
10 & 6430 & 4949 & 1.30 \\
11 & 8166 & 4491 & 1.82 \\
12 & 9447 & 6744 & 1.40 \\
13 & 7545 & 5560 & 1.36 \\
14 & 2408 & 1707 & 1.41 \\
\hline
\end{tabular}

Remarks

$L m f=$ length of mountain front along the foot of the mountain chain. $L s=$ straight-line length of the mountain front. $\operatorname{Smf}=$ mountain-front sinuosity. Locations are shown in Fig. 11.

\subsection{Mountain-front sinuosity $(\mathrm{Smf})$}

Mountain-front sinuosity $(\operatorname{Smf})$ is calculated from the ratio of the length of the mountain front along the foot of the mountain chain $(L m f)$, to the mountain-front length as the crow flies $(L s)$. The $S m f$ index reflects the balance between erosional power, which tends to embay frontal slopes, and tectonic power, which tends to produce a straight mountain front. The index is calculated as

$$
S m f=L m f / L s
$$

The $S m f$ values for active tectonic zones in arid areas are relatively low (Bull and McFadden, 1977), typically between 1.2 and 1.6, while values for slightly active or inactive tectonic areas tend to fall in the ranges 1.8-3.4 or 2-7, respectively (Bull and McFadden, 1977). Smf analysis was previously applied to the Lo River Fault in northern Vietnam, yielding low values (1.11-1.59) that indicate recent uplift of the footwall (Cuong and Zuchiewicz, 2001).

In the present study, we measured the $\operatorname{Smf}$ index for streams around the southeastern margin of the Lampang Basin. The $\operatorname{Smf}$ values in the Ban Mai and Sop Prap areas vary from 1.11 to 1.82 (Table 2). The locations where $S m f$ was determined are shown in Fig. 11.

5.4 Summary of analyses based on geomorphic indices

$S L$ indices for the Thoen Fault, along the southeastern margin of the Lampang Basin, indicate a steeper slope near the mountain front, possibly the result of normal faulting. Moreover, most of the $V f$ and $\operatorname{Smf}$ values obtained for the Ban Mai, Ban Don Fai, and Sop Prap segments are low (0.44-2.75 for $V f$ and 1.11-1.82 for $S m f$; Tables 1 and 2), which may indicate an area of weakly active tectonism characterized by normal dip-slip fault movement.

\section{Trench Investigations}

Based on morphotectonic landforms, detailed topographical and geological maps, ground penetrating radar data, and geomorphic indices developed for the Ban Dan Fai area in the Lampang Basin (Fig. 12), we selected a site for trenching at Ban Don Fai, along the northern segment of the fault (Ban Don Fai trench No. 2; $18^{\circ} 6^{\prime} 19.042^{\prime \prime} \mathrm{N}$, $99^{\circ} 41^{\prime} 14.875^{\prime \prime} \mathrm{E}$; number 1 in Fig. 12). We excavated a trench of $19 \mathrm{~m}$ long, $2 \mathrm{~m}$ wide, and $3.5 \mathrm{~m}$ deep. The sediments exposed in the trench can be divided into six unconsolidated units (excluding the top soil) that are exposed in both sidewalls. A detailed trench log is shown in Fig. 13. Details of the individual units, in descending stratigraphic order, are described below.

Top soil: reddish-brown clayey sand. This is a soil used for agriculture, and organic matter is commonly found. The unit is approximately $30 \mathrm{~cm}$ thick.

Unit A: sand and gravel. The gravels consist mainly of subangular to angular clasts of sandstone and shale, and clast size varies from pebble to cobble. The thickness of this unit ranges from $10 \mathrm{~cm}$ to $1 \mathrm{~m}$.

Unit B: brown clayey sand with gravel. Most of the clasts in the gravel are subangular and consist of sandstone, shale, and quartz. The unit is exposed on the southeastern side of the trench, but was not found on the northwestern side. The thickness of the unit ranges from $10 \mathrm{~cm}$ to $50 \mathrm{~cm}$.

Unit C: brown sandy clay, with a little gravel. Most of the gravel clasts are sandstone. The unit is exposed only on the southeastern side of the trench, where its thickness ranges from 10 to $50 \mathrm{~cm}$.

Unit D: sand with gravel. Most of the gravel clasts (of pebble size) are of sandstone and shale. The unit is exposed on the southeastern side of the trench, but it is absent at the point marked ' $x$ ' in Fig. 13. The thickness of the unit ranges from 10 to $30 \mathrm{~cm}$.

Unit E: reddish-brown clayey sand, with sparsely distributed pebbles. This unit is limited to the southeastern part of the trench, where it is approximately $30 \mathrm{~cm}$ thick.

Unit F: gravel, sand, and silt with carbonaceous clay. The gravel clasts are mainly subangular to rounded, and most consist of quartz, sandstone, and shale. The unit contains graded beds of $10-50 \mathrm{~cm}$ in thickness. A lenticular layer of sand ( $20 \mathrm{~cm}$ thick) occurs between layers of gravel. The total thickness of this unit exceeds $1.5 \mathrm{~m}$.

The grain size of sediment in this trench ranges from clay to coarse gravel. The stratigraphic relationships between unit $\mathrm{F}$ and overlying units indicate that the top of unit $\mathrm{F}$ is an erosional surface (Fig. 13). The sediments in unit F are poorly sorted. Clasts in gravel layers are subangular to rounded, and the unit contains a lenticular layer of sand and graded beds. The clasts are randomly oriented, with some elongate gravel clasts oriented with their long axes at a high angle to bedding. The sedimentary structures indicate that unit F was deposited by a gravity flow (e.g., Steel and Gloppen, 1980). The sediments of units A-E are poorly sorted, and the mixed sand, silt, and gravel of these units was possibly deposited from a sandy gravity flow. The sediments in this trench are laterally continuous, and no faults are observed. 


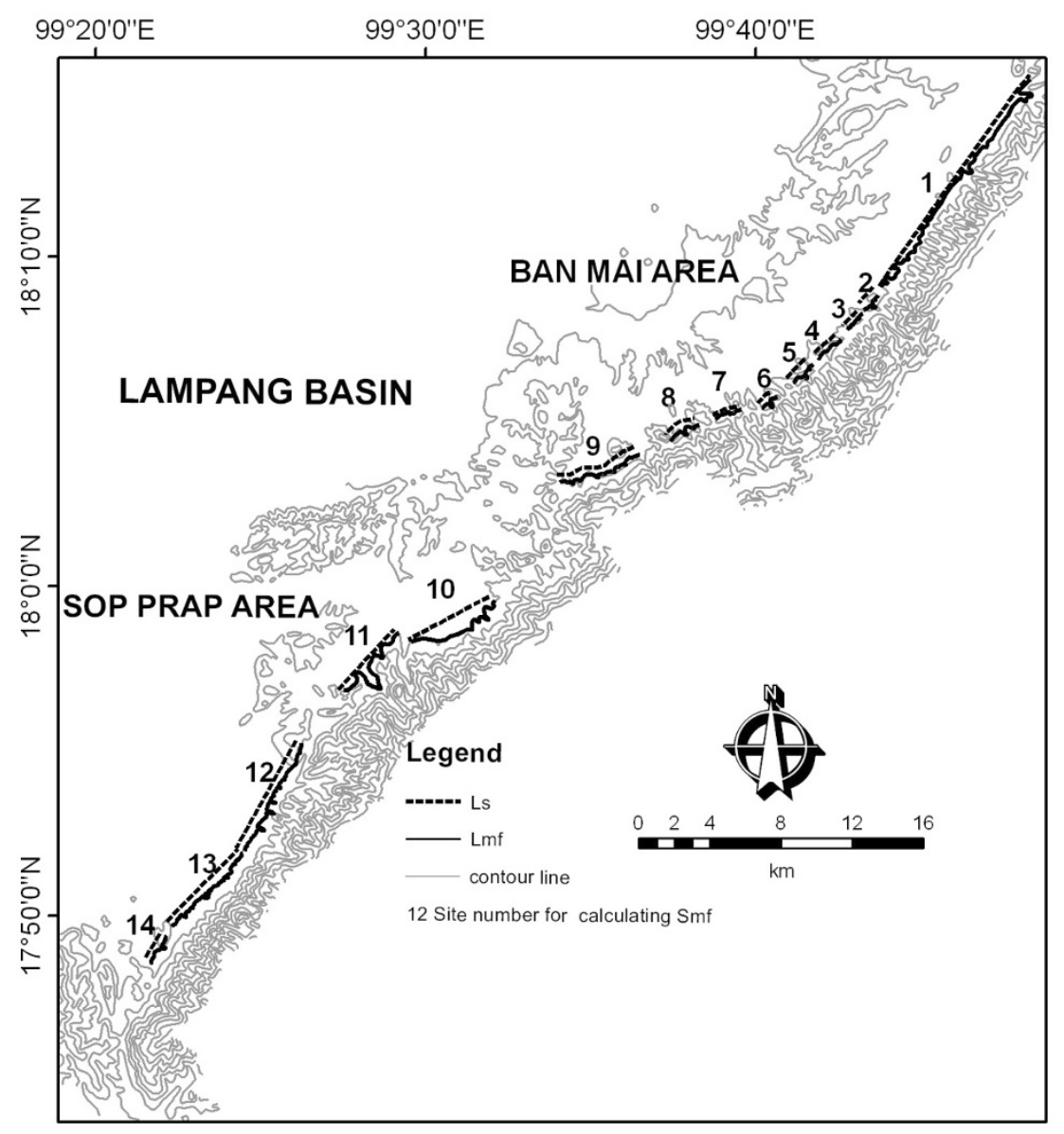

Fig. 11. Map showing the locations used for calculation of the $\operatorname{Smf}$ index near the Sop Prap and Ban Mai areas. $L m f$ is the length of the mountain front, as measured along the foot of the mountain chain (taking into account its sinuosity), and $L s$ is the mountain-front length as the crow flies.

\section{Geochronological Investigations}

The trench-log stratigraphy in Ban Don Fai trench No. 2 shows no evidence for recent fault movement, but to put this finding in context it is necessary to determine the age of the sediments exposed in the trench. Having established the stratigraphy of the Ban Don Fai trench No. 2, we then proceeded to collect samples for OSL and AMS radiocarbon dating.

\subsection{AMS radiocarbon dating}

The ${ }^{14} \mathrm{C}$ method of dating is often applied in archaeology and geology, but the method is only accurate for samples younger than 45,000 years (Roberts et al., 1994). For paleoearthquakes investigations in Thailand, AMS radiocarbon dating is commonly used for determining the age of sediments in a trench. For example, Pailoplee et al. (2009) and DMR (2006) succeeded in dating carbonaceous and charcoal samples, and these ages were then used for estimating the timing of fault movements. In the present study, three carbonaceous clay samples were collected from unit $F$ in the Ban Don Fai trench No. 2 (Fig. 13), and the samples were processed for AMS radiocarbon dating at Beta Analytic Inc. (USA). The dating results are shown in Table 3.

\subsection{Optically Stimulated Luminescence (OSL)}

OSL dating is based on detecting the amount of luminescence and the radiation rate (per year) for the radioactive isotope (Vafiadou et al., 2007). The method is widely used in dating geological sediments such as aeolian quartz-rich sediments, marine sands, and colluvial materials (Murray and Olley, 2002). Six samples from units C, E, and F in Ban Don Fai trench No. 2 were prepared for OSL dating (Fig. 13). Samples were dried, and the water content analyzed. Each sample was sieved using a $0.84 \mathrm{~mm}$ mesh filter for annual dose analysis $(300 \mathrm{~g})$. Grains between 0.25 and $0.075 \mathrm{~mm}$ in size were extracted by re-sieving the remaining sample. Thereafter, these samples were treated with $35 \%$ hydrochloric acid $(\mathrm{HCl})$ for at least 30 minutes to remove carbonates and organic material. Ferromagnetic fragments in the samples were separated from quartz using an isodynamic magnetic separator. Feldspar was removed by treatment with $24 \%$ hydrofluoric acid (HF). X-ray diffraction analysis (XRD) was used to ensure no feldspar remained in the samples; if feldspar was detected, we treated the samples again with hydrofluoric acid until all feldspar had been removed.

Measurements were made using an OSL instrument (Model OSL/TL-DA-15, Ris $\varnothing$ National Laboratory, Denmark) at Chulalongkorn University, Thailand. The instrument was equipped with a ${ }^{90} \mathrm{Sr} /{ }^{90} \mathrm{Y}$ beta source delivering $0.14 \mathrm{~Gy} / \mathrm{sec}$ to the sample. In such a system, the OSL signals from the samples are produced by using Blue-LED ar- 


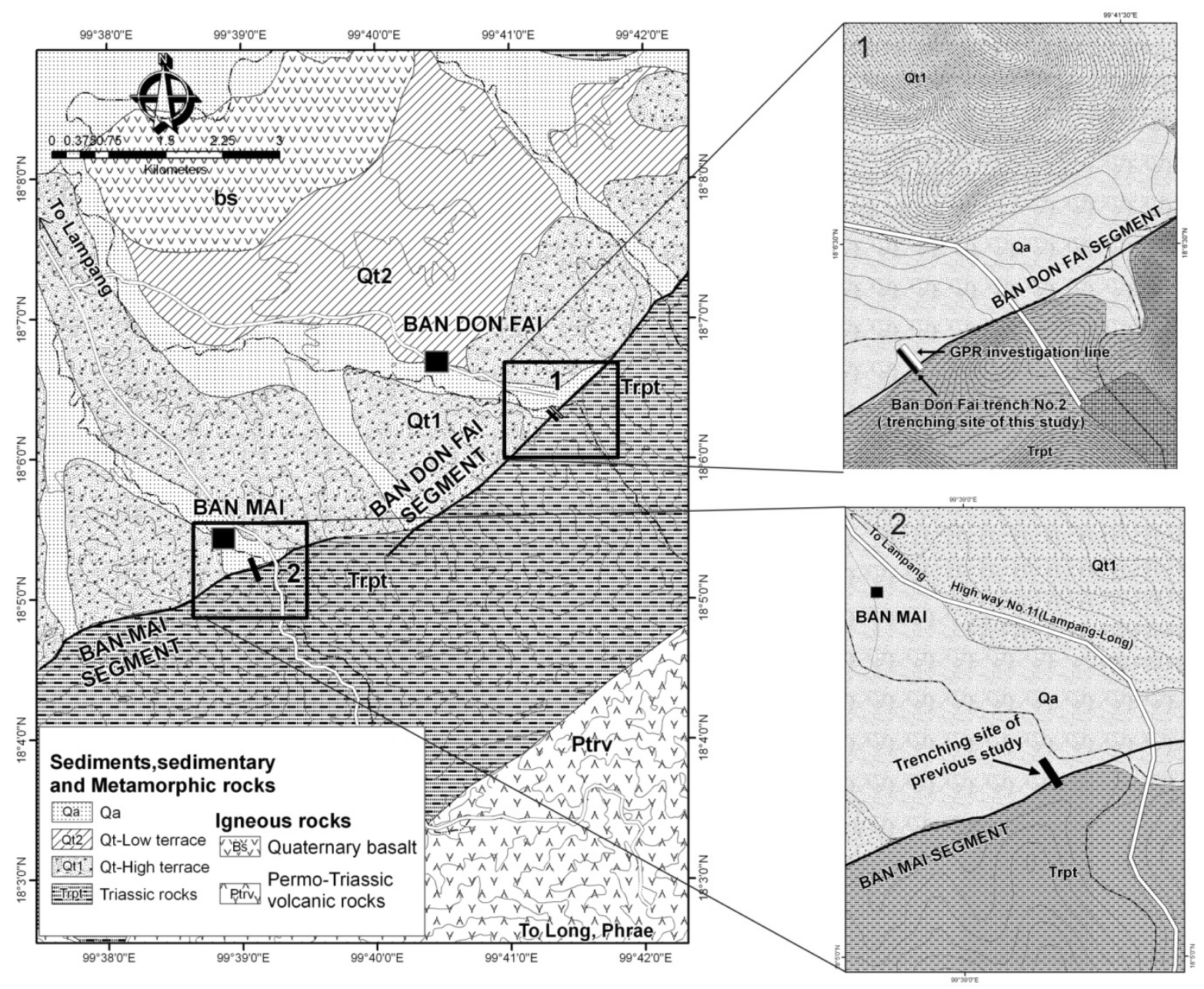

Fig. 12. Shows topographical and geological maps, the survey line (in the Ban Dan Fai area) investigated by ground penetrating radar, and the sites of trenches excavated in this study and in a previous study.

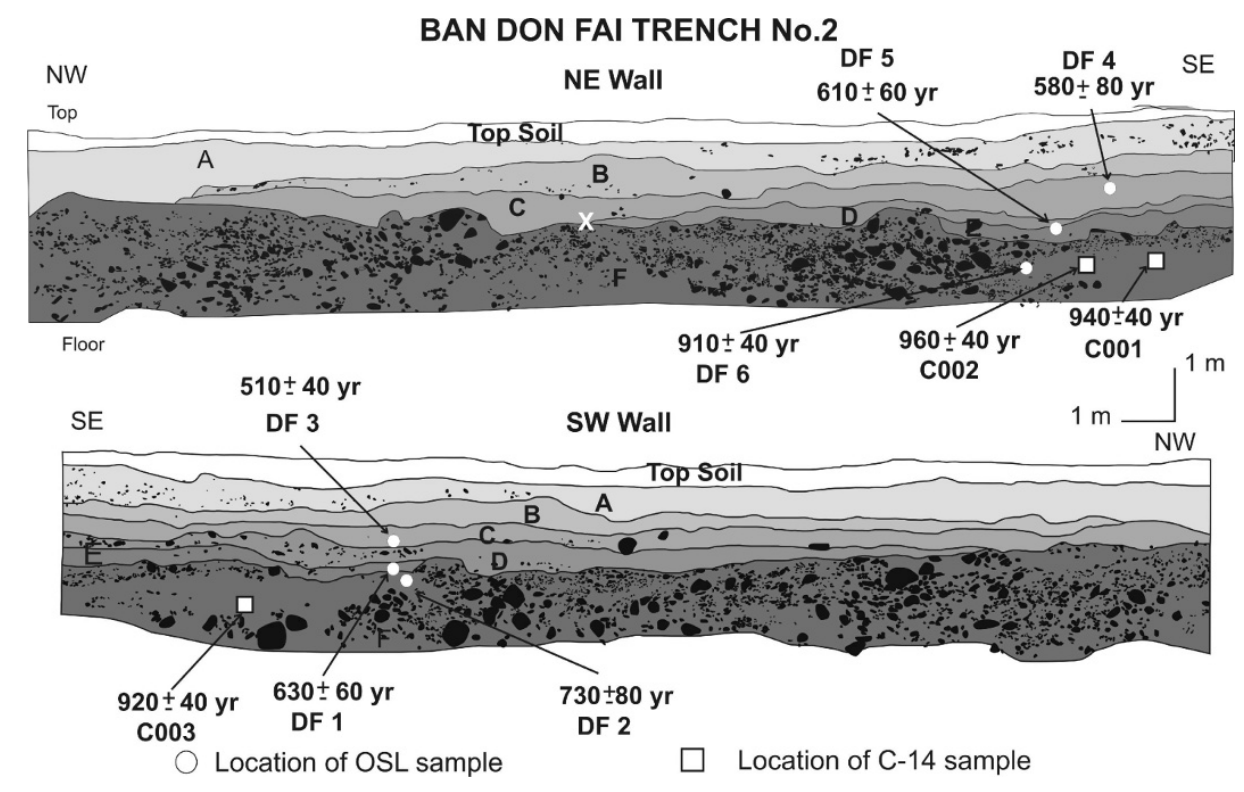

Fig. 13. Trench-log stratigraphy and Holocene age data for Ban Don Fai trench No. 2. The location of the trench is shown in Fig. 12 (number 1). Top soil: clayey sand; A: sand and gravel; B: clayey sand with gravel; C: sandy clay with minor gravel; D: sand with gravel; E: clayey sand; F: gravel, sand, and silt with carbonaceous clay. The point marked ' $\mathrm{x}$ ' indicates the location where unit $\mathrm{D}$ is absent. 
Table 3. Result of AMS radiocarbon dating (C-14) of carbonaceous sediments from Ban Don Fai trench No. 2.

\begin{tabular}{cccc}
\hline Sample No. & ${ }^{14} \mathrm{C}$ measured radiocarbon age \\
$($ yr BP $)$ & $\begin{array}{c}{ }^{13} \mathrm{C} /{ }^{12} \mathrm{C} \\
(\text { per mil })\end{array}$ & $\begin{array}{c}{ }^{14} \mathrm{C} \text { conventional radiocarbon age } \\
(\mathrm{yr} \text { BP })\end{array}$ \\
\hline C001 & $940 \pm 40$ & -25.1 & $940 \pm 40$ \\
$\mathrm{C} 002$ & $940 \pm 40$ & -23.9 & $960 \pm 40$ \\
$\mathrm{C} 003$ & $910 \pm 40$ & -24.6 & $920 \pm 40$ \\
\hline
\end{tabular}

Remarks

Method: AMS-Standard ${ }^{14}$ C. Sample: Organic sediment. Locations of sample sites are shown in Fig. 13.

Table 4. OSL dating results for quartz concentrates from sediment samples collected in the Lampang Basin, northern Thailand.

\begin{tabular}{|c|c|c|c|c|c|c|c|c|}
\hline Sample & $\mathrm{U}(\mathrm{ppm})$ & Th (ppm) & $\mathrm{K}(\%)$ & $\mathrm{W}(\%)$ & $\mathrm{AD}(\mathrm{Gy} / \mathrm{ka})$ & ED (Gy) & Age (Yr) & Error (Yr) \\
\hline DF1 & 3.14 & 15.07 & 2.52 & 1.50 & 4.66 & 2.92 & 630 & 60 \\
\hline DF2 & 3.00 & 15.64 & 2.87 & 2.56 & 5.01 & 3.67 & 730 & 80 \\
\hline DF4 & 2.94 & 12.21 & 2.03 & 7.46 & 3.80 & 2.19 & 580 & 80 \\
\hline DF5 & 3.17 & 15.50 & 2.35 & 5.99 & 4.44 & 2.73 & 610 & 60 \\
\hline
\end{tabular}

Remarks
Locations of samples are shown in Fig. 13.

rays $(470 \pm 30 \mathrm{~nm})$ as stimulation light sources. We applied a single-aliquot regenerative dose (SAR) protocol in order to measure a paleodose for all samples. The paleodoses are summarized in Table 4.

For the annual dose, the concentrations of $\mathrm{U}$, Th, and $\mathrm{K}$ were analyzed using gamma spectrometry at Chulalongkorn University. The annual dose was computed using the concentration of $\mathrm{K}, \mathrm{U}$, and $\mathrm{Th}$ in the standard table described by Bell (1979). The results of annual doses and OSL dating are summarized in Table 4.

Figure 13 shows the stratigraphic units, and the measured OSL and AMS radiocarbon dates for sediments from Ban Don Fai trench No. 2. The OSL ages indicate that the sediments were deposited during the past 910 years. Three AMS radiocarbon dates indicate that the sediments in the lowest unit were deposited from about 960 to 920 years $\mathrm{BP}$, and these dates are consistent with the OSL ages for sediments in unit F. Thus, the OSL method is useful for estimating the age of deposition of the quartz-rich sample. This result is encouraging in terms of the future use of OSL dating.

\section{Discussion}

\subsection{Sense of fault movement}

The Thoen Fault, along the southeastern margin of the Lampang Basin, has been regarded as an active fault (Fenton et al., 1997, 2003; DMR, 2006). Morley et al. (2007) and Fenton et al. (2003) suggested that the fault is characterized mainly by normal dip-slip and subordinate left-lateral slip.

Measurements of geomorphic indices ( $S L, V f$, and $S m f$ indices) in the Lampang Basin are consistent with dip-slip movement on the Thoen Fault. The $S L$ indices from the southeastern margin of the basin indicate steeper slopes near the mountain front, and most of the $V f$ and $S m f$ values from the Ban Mai, Ban Don Fai, and Sop Prap segments are quite low (0.44-2.75 for $V f$ and 1.11-1.82 for $S m f$ ). The geomorphic characteristics of the Thoen Fault are simi- lar to those of the Lo River Fault in northern Vietnam, where values of $V f(0.06-0.61)$ and $\operatorname{Smf}(1.04-1.16)$ are low because of recent tectonic uplift (Cuong and Zuchiewicz, 2001).

The Thoen Fault is well defined by geomorphology, and is evident as sharp lineaments on aerial photographs and satellite images (Fig. 4), associated with morphotectonic landforms such as fault scarps, triangular facets, wine-glass canyons, and a linear mountain front. Detailed interpretations of aerial photographs clearly reveal fault scarps at Ban Mai, Ban Don Fai, and Ban Samai Nuea ((A) and (C) in Fig. 4). A series of triangular facets on the NW-facing escarpment (Fig. 5) might represent stage VIII of Hamblin's model (Fig. 6). A series of streams crossing the Ban Don Fai, Sop Prap, and Ban Mai segments of the fault pass through wine-glass canyons (Fig. 7) and V-shaped valleys, suggesting multiple episodes of tectonic uplift.

A geological survey performed at the Mae Than mine (Morley et al., 2001) in the northern Sop Prap area confirmed the presence of NE-SW-striking normal faults. These normal faults form a right-stepping relay ramp in the eastern part of the mine area (Fig. 14), where a syncline and anticline occur, with axial planes that strike at right angles to the NE-SW-striking fault. The syncline and anticline have been interpreted to represent shortening associated with a left-lateral component of oblique slip on the boundary fault at a restraining right-stepping transfer zone (Morley et al., 2001). Our remote-sensing data, however, suggest that the morphotectonic landforms in the Lampang Basin were caused only by dip-slip normal fault movements, as explained above and as indicated by seismological analysis. For example, Bott et al. (1997) examined the focal mechanisms of three earthquakes in northern Thailand, indicating E-W to NW-SE extension.

A sequence of alluvial gravels and lacustrine clays is cut by a NE-SW-striking normal fault along Highway 11 (from Lampang to Phrae) at $28 \mathrm{~km}$ from Lampang. This offset is exposed on the western side of the main escarpment along 


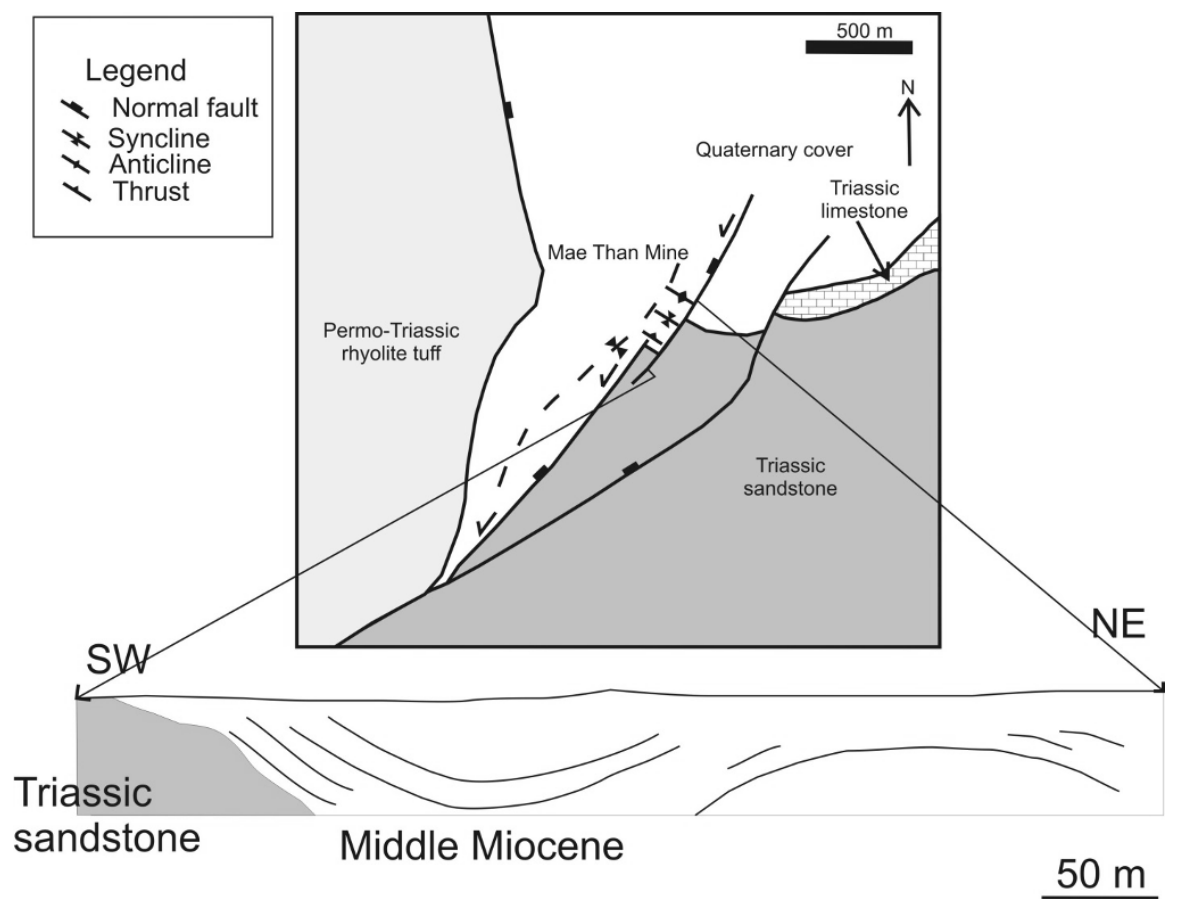

Fig. 14. Geological map of the Mae Than mine, showing a syncline and anticline near the fault tip of the Mae Than fault segment (modified from Morley et al., 2001). The location of the Mae Than fault segment is shown in Fig. 8.

the Ban Mai segment. The total vertical displacement is 1.3-1.6 m (Charusiri et al., 1997; Fenton et al., 2003). The timing of the faulting is interpreted to be Late Quaternary (Fenton et al., 2003). The relationship between this fault and the Thoen Fault remains unknown, although its location and orientation suggest that it is a synthetic fault (i.e., it has the same dip and sense of movement as the main fault) (Fenton et al., 2003).

\subsection{Age of fault movement}

Geomorphological features and geomorphic indices in the study area indicate active normal faulting. However, the sediments in the trench at Ban Don Fai show no clear-cut evidence of recent fault movement. At Ban Don Fai trench No. 2, AMS radiocarbon and OSL dates show that the sediments of the lowest unit (Unit F in Fig. 13) were deposited between 960 and 910 years ago. The lack of evidence in the trench for recent fault movement indicates that the fault is located below the depth of the trench; i.e., the most recent movement upon the fault pre-dates the deposition of the oldest sediments in the trench. In the case that the trench did not intercept the fault trace, the most recent movement on the fault may be younger than the oldest sediments in the trench; however, the location of the trench was decided based on a careful analysis of aerial photographs, and based on the distribution of morphotectonic landforms observed in the field. Thus, it is possible that the most recent movement on the Ban Don Fai fault segment occurred more than 960 years ago. Based on TL dating of sediments at trench sites (Pailoplee et al., 2009), the most recent movement on the Ban Mai segment of the fault took place about 3,800 years ago (2 in Fig. 12), while the last movement on the Doi Ton Ngun segment was about 1,800 years ago. However, the TL method of dating involves uncertainties. The apparent TL ages calculated for fluvial sediments are often
3-8 times higher than TL or AMS radiocarbon dates for adjacent buried soils (McCalpin et al., 1994). Fluvial sediments are usually deposited episodically by water flowing in the river channel. They probably receive limited exposure to light, and as a consequence, they are likely to retain a large inherited TL signal (McCalpin et al., 1994). Alluvial sediments are rapidly deposited by gravity flows, which may also result in a large inherited TL signal. Thus, TL dates for fluvial and alluvial sediments may systematically result in overestimating the ages of deposition (Forman, 1989; McCalpin et al., 1994). For this reason, the TL dating method is unsuitable for determining the deposition ages of fluvial and alluvial sediments in the Lampang Basin.

\section{Conclusions}

The Thoen Fault in the Lampang Basin, northern Thailand, strikes NE-SW. Morphotectonic landforms caused by normal faulting in the Lampang Basin are well represented by fault scarps, triangular facets, wine-glass canyons, and linear mountain fronts. On the other hand, morphotectonic landforms that would indicate strike-slip faulting are not found.

Along the fault at the southeastern margin of the Lampang Basin, the stream length gradient index ( $S L$ index), as measured near the mountain front, records steeper slopes which possibly relate to normal faulting. Moreover, along the Ban Mai, Ban Don Fai, and Sop Prap segments of the fault, the ratio of valley floor width to valley height $(V f)$ is generally low (0.44-2.75), as are values of mountain-front sinuosity $(\operatorname{Smf})$ (1.11-1.82). Low $V f$ values reflect deep V-shaped valleys, and low $\operatorname{Smf}$ values are associated with active tectonic zones. Together, these geomorphic indices suggest an area of weakly active tectonism characterized by dip-slip normal fault movement. 
Although the geomorphological features and geomorphic indices in the study area are consistent with active normal faulting, the sediments exposed in the trench at Ban Don Fai provide no clear-cut evidence of recent fault movement. In Ban Don Fai trench No. 2, AMS radiocarbon and OSL dating indicate that the sediments of the lowest exposed unit were deposited between 960 and 910 years ago. Accordingly, we conclude that the most recent fault movement along the Ban Don Fai segment of the Thoen Fault occurred more than 960 years ago.

Acknowledgments. We would like to thank the Royal Thai Government for supporting this research; the Active fault and Earthquake Research Center, AIST, Japan, for assistance in funding the AMS radiocarbon dating; and the Department of Geology, Chulalongkorn University, Thailand, for help in providing the OSL equipment. We thank the Environmental Geology Division, DMR, for providing all facilities during the fieldwork in Lampang province. Dr. Akira Takada, editor, Dr. Brady Rhodes, and anonymous reviewers are thanked for a thorough review that greatly improved the manuscript. We extend special thanks to Dr. Santi Pailoplee for his advice on OSL dating; Mr. Suwith Kosuwan, Mr. Preecha Saithong, and Ms. Wunnaporn Punyawai for their help during fieldwork and managing the collection of samples; Mr. Surasak Bunlue for his discussion; and Dr. Yu Horiuchi for proofreading parts of the manuscript.

\section{References}

Bell, W. T., Thermoluminescence dating: Radiation dose-rate data, Archaeometry, 21, 243-245, 1979.

Bott, J., I. Wong, S. Prachuab, B. Wechbunthung, C. Hinthong, and S. Sarapirome, Contemporary seismicity in northern Thailand and its tectonic implications, in Proceedings of the International Conference on Stratigraphy and Tectonic Evolution of Southeast Asia and the South Pacific, Bangkok, Department of Mineral Resources, 453-464, 1997.

Bull, W. B., Tectonic Geomorphology of Mountains: A New Approach to Paleoseismology, 316 pp., Malden, U.S.A., 2008.

Bull, W. B. and L. D. McFadden, Tectonic geomorphology north and south of the Garlock fault, California, in Geomorphology in Arid Regions, edited by D. O. Doehring, Proceeding 8th Annual Geomorphology Symposium, State University New York at Binghamton, 115-137, 1977.

Charusiri, P., V. Daorerk, and T. Supajanya, Applications of remotesensing techniques to geological structures related to earthquakes and earthquake-prone areas in Thailand and neighbouring areas: A preliminary study, J. Sci. Res. Chulalongkorn Univ., 21(1), 14-38, 1996.

Charusiri, P., S. Kosuwan, W. Tuteechin, B. Vechbunthoen, R. Suwanwerakamtorn, and T. Jarupongsakul, Studies on causes of earthquakes in Thailand from SE Asian geology structures using Landsat TM-5 images, A final report submitted to National Research Council of Thailand under the research grant from Thailand, Remote sensing center, Bangkok, 1997 (in Thai, abstract in English).

Charusiri, P., V. Daorerk, D. Archibald, K. Hisada, and T. Ampaiwan, Geotectonic evolution of Thailand: A new synthesis, J. Geol. Soc. Thailand, 1, 1-20, 2002.

Charusiri, P., B. P. Rhodes, P. Saithong, S. Kosuwan, S. Pailoplee, W. Wiwegwin, V. Daorerk, C. Hinthong, and S. Klaipongpan, Regional tectonic setting and seismicity of Thailand with reference to reservoir constraction, in GEOTHAI'07 International conference on Geology of Thailand: Towards Sustainable Development and Sufficiency Economy, Bangkok, Thailand, 274-287, 2007.

Cuong, N. Q. and W. A. Zuchiewicz, Morphotectonic properties of the Lo River fault near Tam Dao in North Vietnam, Nat. Haz. Earth Syst. Sci., 1, 15-22, 2001.

Danphaiboonphon, V., Neotectonics of the Theon Fault System, Lampang Basin, Northern Thailand, Master's thesis, Department of Geology, Faculty of Sciences, Chulalongkorn University, Bangkok, Thailand, 2005.

Department of Mineral Resources (DMR), Geological map of Chanwat Lampang 1:250,000, Geological Survey Division, Department of Mineral Resources, Bangkok, 1994.

Department of Mineral Resources (DMR), Active fault map of Thailand, 2006 (Online Article, October 2006), http://www.dmr.go.th/geohazard/ earthquake_n/ActiveFault_Eng.htm, 2006.
Ducrocq, S., E. Buffetaut, H. Buffetaut-Tong, Y. Chimanee, J. J. Jaeger, R. Lacassin, and V. Sutheethrn, Tertiary continental basins of Thailand as a result of strike-slip motions induced by the India-Asia collision, $J$. Southeast Asian Earth Sci., 7, 260, 1992.

Fenton, C., P. Charusiri, C. Hinthong, A. Lumjuan, and B. Mangkornkarn, Late Quaternary faulting in northern Thailand, in Proceedings of the International Conference on Stratigraphy and Tectonic Evolution of Southeast Asia and the South Pacific, Department of Mineral Resources, Dheeradilok, P. (ed. in chief), Bangkok, 19-24 August 1997, 436-452, 1997.

Fenton, C., P. Charusiri, and S. H. Wood, Recent pleoseismic investigations in northern and western Thailand, Ann. Geophys., 46(5), 957-981, 2003.

Forman, S. L., Application and limitation of thermoluminescence to date Quaternary sediments, Quatern. Int., 1, 47-59, 1989.

Ganas, A., S. Shanov, G. Drakatos, N. Dobrev, S. Sboras, C. Tsimi, G. Frangov, and S. Pavlides, Active fault segmentation in southwest Bulgaria and Coulomb stress triggering of the 1904 earthquake sequence, J. Geodyn., 40, 316-333, 2005.

Geological survey of Japan (GSJ), A new series of the Neotectonic Maps of Japan (1:500,000 scale), Bull. Geol. Surv. Jpn., 34(1), 27-37, 1983.

Hack, J. T, Stream-profile analysis and stream-gradient index, J. Res. U.S. Geol. Surv., 1(4), 421-429, 1973.

Hamblin, B. K., Patterns of displacement along the Wasatch Fault, Geology, 4, 619-622, 1976.

Hinthong, C., The study of active faults in Thailand, in Technical Conference on the Progression and Vision of Mineral Resources Development (Department of Mineral Resources), Bankok, Thailand, 129-140, 1995.

Hinthong, C., The study of active faults in Thailand, in Report of EANHMP, an Approach to Natural Hazards in Eastern Asia, Eastern Asia Natural Hazards Mapping Project (EANHMP) and Geological Survey of Japan, 17-22, 1997.

Huchon, P., X. Le Pichon, and C. Rangin, Indo-China Peninsular and the collision of India and Eurasia, Geology, 22, 27-30, 1994.

Keller, E. A. and N. Pinter, Active Tectonics: Earthquake, Uplift, and Landscape, 338 pp., New Jersey, Prentice Hall, 1996.

Kosuwan, S., P. Saithong, A. Lumjuan, I. Takashima, and P. Charusiri, Preliminary results of studies on the Mae Ai segment of the Mae Chan fault zone, Chiang Mai northern Thailand, in The CCOP Meeting on Exodynamic Geohazards in East and Southeast Asia, July 14-16, Pattaya, CCOP, 1-8, 1999.

Lacassin, R., C. Hinthong, K. Siribhakdi, S. Chauviroj, A. Charoenravat, H. Maluski, P. H. Leloup, and P. Tapponnier, Cenozoic diachronic extrusion and deformation of western Indochina: structure and ${ }^{40} \mathrm{Ar} /{ }^{39} \mathrm{Ar}$ evidence from NW Thailand, J. Geophys. Res., 102(B5), 10013-10037, 1997.

Longley, I. M., The tectonostratigraphic evolution of SE Asia, in Petroleum Geology of Southeast Asia, edited by A. J. Fraser, S. J. Matthews, and R. W. Murphy, Geological Society Special Publication No. 126, 311-339, 1997.

McCalpin, J. P., S. L. Forman, and M. Lowe, Reevaluation of Holocene faulting at the Kaysville site, Weber segment of the Wasatch fault zone, Utah, Tectonics, 13(1), 1-16, 1994.

Morley, C. K., A tectonic model for the Tertiary evolution of strike-slip faults and rift basins in SE Asia, Tectonophysics, 347(4), 189-215, 2002.

Morley, C. K., Variations in Late Cenozoic-Recent Strike slip and ObliqueExtensional geometries, within Indochina: Influence of pre-existing fabrics, J. Struct. Geol., 29, 36-58, 2007.

Morley, C. K., N. Woganan, N. Sankumarn, T. B. Hoon, A. Alief, and M. Simmons, Late Oligocene-Recent stress evolution in rift basins of northern and central Thailand: Implications for escape tectonics, Tectonophysics, 334, 115-150, 2001.

Morley, C. K., C. Haranya, W. Phoosongsee, S. Pongwapee, A. Kornsawan, and N. Wonganan, Activation of rift oblique and rift parallel preexisting fabrics during extension and their effect on deformation style: examples from the rifts of Thailand, J. Struct. Geol., 26(10), 1803-1829, 2004.

Morley, C. K., S. Gabdi, and K. Seusutthiya, Fault superimposition and linkage resulting from stress changes during rifting: Examples from 3D seismic data, Phitsanulok Basin, Thailand, J. Struct. Geol., 29(4), 646663, 2007.

Murray, A. S. and J. M. Olley, Precision and accuracy in the optically stimulated luminescence dating of sedimentary quartz, Geochronometria, 21, 1-16, 2002.

Nutalaya, P., S. Sodsri, and E. P. Arnold, Series on Seismology Vol. IIThailand, in Technical Report, editd by E. P Arnold, 402 p., Southeast 
Asia Association of Seismology and Earthquake Engineering, Bangkok, 1985.

O'Leary, J. and G. S. Hill, Tertiary basin development in the southern plains Thailand, in Proceedings of the International Symposium on Intermountain Basins: Geology and Resources, edited by T. Thanasuthipitak and P. Ounchanum (Chiangmai University), 254-264, 1989.

Pailoplee, S., I. Takashima, S. Kosuwan, and P. Charusiri, Earthquake activities along the Lampang-Thoen fault zone, Northern Thailand: Evidence from paleoseismological and seismicity data, J. Appl. Sci. Res., 5(2), 168-180, 2009.

Pakcham, G. H., Plate tectonics and the development of sedimentary basins of the dextral regime in Western Southeast Asia, J. Southeast Asian Earth Sci., 8(1-4), 497-511, 1993.

Peltzer, G. and P. Tapponnier, Formation and evolution of strike-slip fault, rift, and basin during the India-Asia collision: An experimental approach, J. Geophys. Res., 93(B12), 15,085-15,117, 1988.

Picotti, V., P. Alessio, and P. J. Frank, Topographic expression of active faults in the foothills of the Northern Apennines, Tectonophysics, 474, 285-294, 2009.

Polachan, S., S. Pradidtan, C. Tongtaow, S. Janmaha, K. Intarawijitr, and C. Sangsuwan, Development of Cenozoic basins in Thailand, Mar. Petrol. Geol., 8, 84-97, 1991.

Reading, H. G., Characteristics and recognition of strike-slip fault system, Int. Assoc. Sedimentol., Spec. Publ., 4, 7-26, 1980.

Rhodes, B. P., R. Perez, A. Lamjuan, and S. Kosuwan, Kinematics and tectonic implications of the Mae Kuang Fault, northern, Thailand, $J$. Asian Earth Sci., 24(1), 79-89, 2004.

Roberts, R. G., R. Jones, and M. A. Smith, Beyond the radiocarbon barrier in Australian prehistory, Antiq. J., 68, 611-616, 1994.

Siribhakdi, K., Seismogenic of Thailand and periphery, in Proceeding of the 1st Workshop on Earthquake Engineering and Hazard Mitigation, edited by P. Lukunaprasit et al., Bangkok, Chulalongkorn University, November 1986, 151-158, 1986.

Steel, R. and T. G. Gloppen, Late Caledonian (Devonian) basin formation, Western Norway: sign of strike-slip tectonics during infillings, Spec. Publ. Int. Assoc. Sedimentol., 4, 79-103,1980.

Tapponnier, P., G. Peltzer, and R. Armijo, On the mechanism of collision between India and Asia, in Collision Tectonic, edited by M. P. Coward and A. C. Ries, Geological Society, London, Special Publication, 19, 115-157, 1986.

Thiramongkol, N., Neotectonism and rate of uplift in the eastern margin of the lower central plain of Thailand, in Proceedings of the Workshop on Economic Geology Tectonics, Sedimentary Processes and Environment of Quaternary of SE Asia, edited by N. Thiramongkol, Had Yai, IGCP, 35-44, 1986.

Troiani, F. and M. Della Seta, The use of the Stream Length-Gradient index in morphotectonic analysis of small catchments: A case study from central Italy, Geomorphology, 12(1), 159-168, 2008.

Vafiadou, A., A. S. Murray, and I. Liritzis, Optically stimulated luminescence (OSL) dating investigations of rock and underlying soil from three case studies, J. Archaeol. Sci., 34, 1659-1669, 2007.

Wallace, R. E., Geometry and rates of change of fault-related fronts, northcentral Nevada, J. Res. U.S. Geol. Surv., 6, 637-650, 1978.

Wiltschko, D. V., L. Hassler, J. H. Hung, and H. S. Liao, From accretion to collision:Motion and evolution of the Chaochou Fault, Southern Taiwan, Tectonics, 29, TC2015, doi:10.1029/2008TC002398, 2010.

W. Wiwegwin (e-mail: Weerachat23@yahoo.com), Y. Sugiyama, K. Hisada, and P. Charusiri 